\title{
THE ROLE OF PRIVATE SECURITY IN THE PROTECTION OF CRITICAL INFRASTRUCTURE IN URBAN AREAS
}

\author{
Oliver BAKRESKI, PhD \\ Faculty of Philosophy, Institute of Security, Defence and Peace \\ E-mail: bakreski@yahoo.com
}

\begin{abstract}
Protecting critical infrastructure is a serious challenge for the security sector in a society and is a major concern not only for public safety but also for private security, as it becomes more than obvious that critical infrastructure is exposed to security threats. Hence, steps are taken by the security sector on a day-to-day basis in protecting the critical infrastructure that has always had a lot of knowledge about the functioning of the state. It is therefore in the interest of providing an integrated approach that brings together all the components of the security sector and links the separate aspects of business or organization. Hence, the idea in this paper is to point out the role and significance of private security in the protection of critical infrastructure in urban areas and to point out all social relevance and value from the aspect of proper, responsible and legitimate operation of the private security sector.
\end{abstract}

Keywords: security, private security, urban security, protection, critical infrastructure,

\section{Introduction}

The global private security market, from physical security to alarm systems, armed transport and other services to commercial, government and residential customers, is expected to reach a value of about $\$ 240$ billion by 2020 . Also, according to statistics, at the international level, the private security industry has seen an increase of $6 \%$, which is a higher growth than the global economy itself. The fastest growing markets are found in Asian countries, while India and China are the largest demanders (European Commission, 2009).

Leading companies offering security services operate in more than a dozen countries and their annual profits vary from $\$ 3$ billion to $\$ 8$ billion, and the number of employees in some companies averages to several thousand people and is engaged in $80 \%$ of companies that are on list the most influential according to Fortune 1000 Companies (2018). Globally, according to the population, the United States is considered the world's largest private security market, employing around 1.5 million and 2 million people, making it three times the number of police officers (Zendelovski, 2016: 350).

Within the European framework, the European Confederation for private security is the representative agent of the European private security sector $(\mathrm{CoESS})$ representing the interests of 
24 national private security associations from EU Member States and candidate countries. This Private Security Confederation before the European Commission represents the interests of some 45,000 legal entities engaged in private security activities with approximately 2 million licensed workers for private security. In comparison, the official Eurostat figure amounts to 1.6 million police officers in Europe in 2016, a figure that over the years is decreased by $3.4 \%$ compared to 2009 (Eurostat News, 2019), which confirms the general tendency for a growing dislocation of the security function to the private sector.

From the outlined above, it can be concluded that private security companies have a significant share and influence in the economic sphere, indirectly in the political sphere. Their services may also include an advisory role in the reform of state security institutions (such as the private military company MPRI in Iraq), in the preparation of doctrines and concepts, as well as in the procurement of arms (the case with the Republic of Georgia) (Kemeroff, 2018). Private security companies depending on their organizational form, are able to offer military education and training, including support in the form "army to army", training effectiveness for driving armored personnel carriers, tanks and artillery, theoretical and practical training for command and control processes at the level of battalion and brigade, as well as instructions and he development of defense information systems (Central Register). Also, in accordance with the organizational form and registered activity, these entities can offer services for the education and training of forces for law enforcement, leadership development, organizational evaluation, as well as strategic planning. Additionally, according to the activity of these entities, they contribute toward staffing, strategic security integration and increase of the levels of security in commercial businesses and so on.

When it comes to analyzing the private security industry at the national level, the focus is on the following aspects: a) economic aspect: private security markets, private security contracts, private security companies, private security personnel, b) legal aspect: legislation of the private security, control and sanctions, collective agreements, employment conditions and restrictions, special conditions, powers and competencies, armaments and K9, training and related preparations, public-private partnership, etc. (CoESS). In the domain of national security, too, the focus is set on law enforcement, capacity building, and issues related to ecology and the environment, critical infrastructure protection and ensuring safety in urban areas.

The use of private security and military companies for multiple purposes at home and abroad is obviously here to remain. However, despite this presence of private security companies in international conflicts and the protection of local property, institutions and individuals, there is an open debate about their use in the academic community, by legal experts, military professionals, etc. (Griffing, 2019).

\section{The Need for Private Security}

The increased demand and the presence of private security is a challenge for fundamental political assumptions that are based on the postulate that the idea of security is in the essence of a public good and it is at the core of the modern conception of sovereignty. The monopoly on 
the use of force by the state is an indicator of the level of sovereignty. In the era of post modernism and the rise of private security and reducing the disparity between public security-private security agencies in ensuring peace and order, crime control and the rule of law and the maintenance of internal security challenges the deeply embedded political discourse that the monopoly of the use of force belongs to the state. However, the overall process is an expression of the clear synergy in the performance of the basic function of shared responsibility of public and private security, and that this process alone provides an ethical approach in the exercise of this social function (Bakreski et al, 2018).

Nowadays, the focus which targets private security receives a great deal of public attention through political and expert debates about the legitimacy of the activity, modification and bringing new legal regulations that set in a frame the modern form of "mercenary", as well as solving the dilemma over whether the use of force shifts to a less pompous but consistent process of security transformation in the matters of commercial security.

The effects of this security transformation in the domain of private security raise issues concerning legality and justification in carrying out specific tasks. Regarding the implications of privatization of security, it is inevitable to look at the social factors that contribute to the growth of the need for private security services (Kekovic et al, 2016).

\section{Private Security in Critical Infrastructure Protection}

Critical infrastructure as a vital, complex and interconnected, structurally connected entity is of exceptional importance and importance for the smooth functioning of the state. It is a clear dialectic that connects the industrial sector, the communication systems, the energy sector and other sectors, systems and networks that are of great importance to the state because they provide the necessary stability. Hence, the disruption or interruption of the work of certain sectors / systems can lead to serious consequences that may have a debilitating effect on the security of the state, the national economy, the economic development and prosperity of the stable energy sector, respectfully that is, the disruption or interruption of only one of these sectors can lead to serious consequences for other critical sectors (Bakreski et al, 2016).

Today, critical infrastructure is threatened by two factors. The first is the natural factor and this includes the dangers of earthquakes, fires, floods, epidemics, etc., and the second factor regarding the intentionally caused damages (theft, vandalism, terrorism, etc.) (Flammini, 2012: 9). Therefore, the threats to critical infrastructure can be artificial as a result of terrorism or other criminal activities, but they can be natural, caused by weather, such as storms, floods or other environmental disasters. Also, critical infrastructure can be threatened by diseases, pandemics, and all of which affect a large number of critical staff (CoESS 2010).

In general, the state is responsible for protecting the citizens and providing a certain level of social functionality and security, but the fact is that some of the critical infrastructure is stateowned and part is privately owned (domestic or foreign companies). Many Western countries gave the majority of critical infrastructure to private enterprises, and the state in order to ensure the smooth operation and functioning of critical infrastructures (Mihaljevic et al, 2013) - is 


\section{Secuurity}

making great efforts to ensure the cooperation of state structures and private individuals. Due to the intertwined relations, there are owners who do not possess the same values and attitudes for securing the critical infrastructure system. Hence, there is a need for a multivariate approach of the state and the operators. ${ }^{37}$

Implying that the general commitment for critical Infrastructure protection should be especially apostrophized, due to the acknowledgement that this segment is essential, respectfully that is an essential part of national security of each country, hence its protection is the ultimate goal and priority of each country especially if having in consideration that each country is exposed to social deviations (for example : theft, fraud, industrial spying, sabotage, diversion, malicious damage, etc.), natural disasters, technical and technological accidents, human failures, etc., which can cause major human loss and material damage. If specific forms of endangerment are included in these elements, including the use of modern weapons and advanced technologies, including nuclear material, chemical and biological weapons, etc., it is a clear signal that there is a serious security risk, complemented by the likelihood that such weapons are used in acts of unlawful conduct and critical infrastructure, imposes the need to create appropriate mechanisms for the protection of critical infrastructure.

\section{Contemporary Urban Areas and Private Security}

Private security contractors have gained an undisputed position in the national and international security environment (Baljak 2015). Their operations extend to every continent, and according to statistics, half of the global population lives in a country in which the number of employees in the private security sector is higher than the number of state police officers (Provost 2017).

In this context, it is important to point out that the government's "outsourcing" or contracting with private service firms is not the sole motivator that fosters private security. In fact, states, according to factual data, are not the primary clients of private security service providers; rather it is the industry, which counterpoise about $70 \%$ of the total number of customers in Europe.

In many countries in transition and development, personal security as well as residential security services are seen as a status symbol and wealth indicator, providing protection and social status. Physical security, in particular, in many developing countries is more cost-effective and cheap than investment in modern technology for the same needs, primarily because of higher costs, handling and maintenance.

Regarding the function and performance of tasks in the field of security and protection of private buildings in urban areas, one of the priorities for successful maintenance of the optimal

\footnotetext{
37 In Germany, 4/5 of critical infrastructure are in private hands. In the United States, about $85 \%$ of critical infrastructures are privately owned, but the reality is that market forces alone are not sufficient to provoke the necessary protection investment in P. Auerswald, LM Branscomb, TM La Porte, E.Michel - Kerjan - The Chalenge of Protecting Critical Infrastructure - Issues in Science and Technology, 2005, p. 77.
} 


\section{Security}

level of security is timely planning, undertaking the necessary measures and preparation of security plans.

When making plans and taking measures to ensure a certain object, it is necessary to take into account the following aspects: risk assessment of the facility; the immediate physical environment; preventive technical security measures; measures for technical, biological and chemical protection; plan or map of the building as well as additional facts about the surrounding area of the building, construction, immediate environment, communication and accessibility on the ground; emergency protection measures of the object (fire, flood, earthquake or other natural disaster, etc.)., defense plan for a possible attack; and a detailed and comprehensive security assessment that needs to be constantly updated and reflect the actual current situation (Komora 2016).

\section{Trends and tendencies in the positioning of the private security}

Security as a modern concept, which is a consolidation of the aspect of public good and public monopoly, further enriched by the modern trend of privatization of security, is a process of connection and transformation.

Privatization of security is a consecutive element of the shift of the relation territory - authorities - rights. Current circumstances are not just a simple erosion of the use of power by the state, a point of view that is not uncommon when analyzing the concept of private security. The terminology that prevails in this discourse contains concepts such as deregulation, financial and trade liberalization, privatization, etc., to describe the changed power of the state in this economic sphere. Hence, this terminology emphasizes the withdrawal of the state, although additional focus is needed to be put at all the modes in which the state participates in setting up a new framework with which globalization further expands, and parallel transformations occur within the countries themselves (DCAF).

This process can be analyzed in three directions of movement of contemporary political and economic structures as follows:

- Process of division where prior public functions are transferred to private actors;

- Development of capacities by private security actors that enable their activity on a global level; and

- Process of re-formation, that is, the environment in which the new actors, with the interoperability they achieve in the process of globalization, operate and are part of the burning security problems.

Basically, in terms of transfer of the powers of the state apparatus to the private security sector, this transformed domain of activities and competences is a different kind of constitutive arrangement, a subject of clear definition and regulation. With the contemporary security concept, in which private security is an integral part of the overall concept of security, the state retains territorial sovereignty, with its geographical fixity and exclusivity, features a set of facil- 
ities at disposal, which in certain circumstances allow the development of the concrete security system in order to contribute to national and global security.

In this process, two important parameters need to be highlighted as follows: the first transformation, and the second - the transfer of powers, which is partial and it does not signify that the state loses its powers or that the concept of national security fades. More precisely, it can be said that it is becoming a sort of process of re- articulation through which certain components of the state transit. Precisely, the disbanding of one part of the state has implications on other parts, simultaneously altering the power relations between different institutions, agencies and organizations in the state itself. This is not a process that is influenced exclusively by external forces that cause erosion of the state, but a combination of the restructuring of the institutions and the relations of power and powers in the state apparatus itself.

In the field of security, in particular, the interrelated processes of partial dismantling, development of private facilities and the reorganization can be perceived through retrospection of three changes in security practices that have evolved over the period of the past few decades, including neoliberalism, commodification and risk. The security sector was initially resistant to the neoliberal ethos unlike other public sectors, however, not immune to the pressure, so that, in recent years, security has transformed and is provided on the principle of the neoliberal model of governance. As a result, police forces in many countries were faced with the need to adapt to new type of management trends and strategies that will contribute to cost-effectiveness, results-oriented and increased efficiency. In addition, public- private partnerships appear as a form of performance of the police work, and there is a certain movement towards contracting activities between professionals from the public police services and a social network of actors in order to prevent the violation of the order and suppression of crime (Svet bezbednosti 2014).

Furthermore, in regard of designation of public funds for the needs of internal and external security (police and military), the fiscal constraints imposed in the past economic recession led to an increase in private security profits. Although there can be no sign of equality between cutbacks in public budgets and demand for services from the private security sector. Also, the outsourcing policy and the allocation of funds for carrying out state affairs to private entities does not imply an automatic withdrawal of the state from the provision of security, i.e. it is more related to the re-location of the execution of that function. In this segment, in addition to fiscal constraints, it is necessary to mention the complex process of commodification, that is, the efforts from corporations, individuals, communities, etc., to ensure security activities, in addition to the state, which in turn contributes to their involvement in safety at all levels.

The increased role that private security plays in all social spheres, in other words, forms a part of the general intensification of security activities across social segments. These processes are often triggered by the state itself, which responds to the increased demand, which in turn stems from the concept of commodification and the constant sense of risk exposure. 


\section{Conclusion}

Protection of critical infrastructure is a precondition, a presumption for the protection of other broader social values, and the critical infrastructure itself can be considered as instrumental and remedial value. This implies that critical infrastructure could be defined as something that is essential for the economy, for the state and society, commonly identified as complex tangible and intangible systems, whose disruption in functioning or destruction could create long-term adverse effects on the fundamental values of the economy, the state and the society as a whole. So, to the critical infrastructure represents a "blood flow" for the smooth functioning of the basic elements of society, and, analogously, their protection is a priority for every society, because it is both indispensable and vital and certainly vital.

Hence, the concept of private security in the protection of critical infrastructure is widely accepted concept that relates to improved methods of work and functioning of certain sectors, that includes a broad platform for the realization and concretization of certain tasks for improvement and protection of the vital infrastructure facilities.

Regarding the threats and risks to critical infrastructure in urban areas, the dilemma is that threats are directly related to global security challenges, including contemporary terrorism. It is therefore necessary to take appropriate steps with regard to the prevention, preparedness and response to terrorist attacks on critical infrastructure in urban areas that will be in line with the European Program for the Protection of Critical Infrastructure.

The Macedonian state should take steps to coherently implement measures to improve the protection of critical infrastructure and define the obligations and duties of all stakeholders in the country concerned with this issue. The implementation of the measures is directly related to having, i.e., to lacking the appropriate assessment that should indicate or assume a particular threat. The assessment of the risks to critical infrastructures themselves counterpoises a process, which analyzes the security information collected by determining priorities in terms of criteria, evaluation and probability.

\section{References}

1. Alexandra, Andrew, Baker, D., P., Caparini, M. (2008): Private Military and Security Companies: Ethics, Policies and Civil-Military Relations.

2. Arduino, Alessandro (2018): China's Private Army: Protecting the New Silk Road. Palgrawe Macmillan. Shanghai Academy of Social Sciences. UNITO - Shanghai China.

3. Arduino, Alessandro, Gong, Xue (2018): Securing the Belt and Road Initiative: Risk Assessment, Private Security and Special Insurances along the new wave of Chinese Outbound Investments. Springer, Singapore.

4. Benny, J., Daniel (2017): Private Investigation and Homeland Security. CRC Press, Taylor \& Francis Group.

5. Boggero, Marco (2018): The Governance of Private Security. Johns Hopkins University. Palgrawe Macmillan. 
6. Carmola, Which: (2010) Private Security Contractors and New Wars: Risk, Law and Ethics. Routledge, New York.

7. Del Prado, H., L. (2013): Private Military and Security Companies and the UN Working Group on the Use of Mercenaries. Oxford University Press.

8. Dempsey, S. John (2010): Introduction to Private Security. Wadsworth, Cengage Learning, 2010.

9. George, Bruce, Kimber, Simon (2014): The History of Private Security and its Impact on the Modern Security Sector. Springer.

10. Gill, Martin (2014): The Handbook of Security. Second Edition. Palgrave Macmillan, UK.

11. Hess, M., Karen (2009): Introduction to Private Security: Fifth Edition. Cengage Learning, Wadsworth.

12. Morrison, Melissa (2015): Understanding the Emergency of Private Security Companies \& Variance in Security Contracting. University of Ottawa, Canada.

13. Nathan, J., Andrew, Scobell, Andrew (2015): China's Search for Security. Columbia University Press, New York.

14. Nemeth, Charles (2012): Private Security and the Law. Fourth Edition. Elsevier, Oxford, UK.

15. Nemeth, P., Charles (2017): Private Security: An Introduction to Principles and Practice. Taylor \& Francis Group.

16. Ortiz, C., (2010): Private Armed Forces and Global Security. Contemporary Military, Strategic and Security Issues. Praeger, Santa Barbara.

17. Schiff, R. (2008): The Military and Domestic Politics. A Concordance Theory of Civil-Military Relations. Routledge.

18. Varin, Caroline (2015): Mercenaries, Hybrid Armies and National Security: Private Soldiers and the State in the $21^{\text {st }}$ Century. Taylor and Francis Group, London and New York. 